\title{
On the identity of Porcellana paivacarvalhoi Rodrigues da Costa, 1968 (Crustacea: Anomura: Porcellanidae)
}

\author{
Luciane Augusto de Azevedo Ferreira ${ }^{1,2}$ \& Marcos Tavares ${ }^{1,3}$ \\ 1 Universidade de São Paulo (USP), Museu de Zoologia (MZUSP). São Paulo, SP, Brasil. \\ ${ }^{2}$ ORCID: http://orcid.org/0000-0003-1683-9962. E-mail: lucianeaaf@gmail.com (corresponding author) \\ 3 ORCID: http://orcid.org/0000-0002-7186-5787.E-mail:mdst@usp.br
}

\begin{abstract}
Porcellana paivacarvalhoi Rodrigues da Costa, 1968, described from southeastern Brazil (São Sebastião, São Paulo), is morphologically similar to the eastern Atlantic P. platycheles (Pennant, 1777), and also to the west African P. africana Chace, 1956. The synonymy between $P$. paivacarvalhoi and $P$. platycheles was proposed by previous authors without examination of any specimens of $P$. platycheles, nor did they considered the morphological similarities between $P$. paivacarvalhoi and $P$. africana. This synonymy has been implicitly accepted without further analysis. The recent discovery of one male and two females syntypes of $P$. paivacarvalhoi has prompted new investigations into the status of $P$. paivacarvalhoi as a junior synonym either of P. platycheles or P. africana. Porcellana paivacarvalhoi is redescribed and illustrated based upon its lectotype herein designated. It is confirmed to be a junior synonym of $P$. platycheles; all evidence suggests that $P$. africana is a distinct, separate species. All previous records of $P$. platycheles from the Brazilian coast are reviewed. Its presence in southeastern Brazil in the late 1960's most probably represents an historical case of human-mediated introduction by shipping activities. Porcellana platycheles did not manage to establish itself in São Sebastião, nor has it been recorded subsequently elsewhere in Brazil.
\end{abstract}

Key-Words. Bioinvasion; Lectotype designation; Porcellana africana; Porcellana platycheles; Western Atlantic.

\section{INTRODUCTION}

Rodrigues da Costa (1968) described Porcellana paivacarvalhoi based on 4 males and 3 females caught in the littoral zone of São Sebastião, São Paulo. As no holotype was selected, all seven specimens are therefore syntypes. The status of $P$. paivacarvalhoi as a valid species remained unchallenged until Veloso \& Melo (1993) examined a supposed male paratype [sic] (MZUSP 8951) and proposed that $P$. paivacarvalhoi was a synonym of Porcellana platycheles (Pennant, 1777). That synonymy has been implicitly accepted subsequently without further analysis (Melo, 1999; Rodríguez et al., 2005; Osawa \& McLaughlin, 2010; Griffiths et al., 2018).

The specimens of $P$. paivacarvalhoi originally described by Rodrigues da Costa were actually in his collections before they (or part thereof) went to the Museu de Zoologia, Universidade de São Paulo, Brazil (MZUSP) in 1987. The specimen MZUSP 8951 studied by Veloso \& Melo (1993) no longer exist in MZUSP. However, the recent finding of 3 syntypes of P. paivacarvalhoi prompted us to revisit the status of $P$. paivacarvalhoi as a synonym of $P$. platycheles.
It has been confirmed recently that specific status should be given to Porcellana platycheles africana Chace, 1956, a shallow water species originally known from western Sahara to Senegal, and recently introduced to South Africa (Griffiths et al., 2018; see also d'Udekem d'Acoz, 1999). Porcellana platycheles and $P$. africana differ morphologically from each other only in minor details. Their strong morphological similarity in addition to the human-mediated introduction of $P$. africana into the South African coast, has prompted us to clarify the identity of P. paivacarvalhoi based upon its type material.

Since its original description, P. paivacarvalhoi remains briefly and poorly described and no prior illustrations of this species have been published. Therefore, this opportunity is taken to redescribe and illustrate the lectotype as herein designated. All previous records of $P$. platycheles from the Brazilian coast are reviewed.

\section{MATERIAL AND METHODS}

The studied specimens are deposited in the collections of the Museu de Zoologia, Universidade 
de São Paulo, Brazil (MZUSP), Museu de História Natural Capão da Imbuia, Curitiba, Brazil (MHNCl) and Museu de Oceanografia da Universidade Federal de Pernambuco, Brazil (MOUFPE).

Abbreviations used include: Mxp 3, maxilliped 3; P1, cheliped; P2-P4, pereopods 2-4. Measurements: cl, carapace length, taken from the front to the posterior median margin of the carapace; cw, carapace width, taken at the level of its widest point, in millimeters ( $\mathrm{mm})$.

\section{RESULTS AND DISCUSSION}

\section{Family Porcellanidae Haworth, 1825 Genus Porcellana Lamarck, 1801 Porcellana paivacarvalhoi Rodrigues da Costa, 1968 (Figs. 1A-J; 2A-D)}

Type material: male lectotype, cl 10.3, cw 9.6 (MZUSP 40050), Brazil, São Paulo, São Sebastião, Praia de São Francisco, H. Rodrigues da Costa coll. Paralectotypes: 1 female, cl 10.0, cw 9.3 (MZUSP 10621), 1 female cl 10.5, cW 10.6 (MOUFPE 7734). Same data as lectotype.

Comparative material: Porcellana platycheles (Pennant, 1777) (Figs. 2E, F; 3A-J): France: 1 male, cl 4.4, cw 4.2, 5 females, cl 5.0 to 9.6, cw 4.5 to 8.8 (MZUSP 18815), îles Chausey, Granville, K. Baba et al. coll., 26-31.viii.1996, intertidal. 3 males, cl 10.4 to $11.8, \mathrm{cW} 9.3$ to 11.4 (MZUSP 36347), Rothéneuf Le Pont, Saint-Malo, Bretagne, 29.xii.1993. 7 males, cl 5.2, cw 4.8 to cl 11.8, cw 11.0, 7 ovigerous females, cl 8.1, cw 7.7 to cl 10.9, cw 10.0 (MZUSP 16261), Roscoff, Bretagne, J.-M. Amouroux coll., vi.2004. 2 males, cl 10.6, cw 9.8 and cl 10.8, cw 10.1 (MZUSP 6807), Quiberon, Bretagne, M. Türkay coll., 02.ix.1981. 2 males, cl 4.4, cw 3.9 and cl 5.7, cw 5.1, 1 female, cl 4.6, cw 4.5 (MZUSP 16408), Biarritz, J.-M. Amouroux coll., 20.ii.2004. Portugal: 1 male, cl 8.2, cw 7.8 (MZUSP 36759), Praia da Poça, São João do Estoril, Estoril, Lisboa, $38^{\circ} 42^{\prime} 04^{\prime \prime} \mathrm{N}-09^{\circ} 23^{\prime 2} 26^{\prime \prime W}$, L.R.L. Simone coll., 13.vii.2014. 3 males, cl 9.7 to 10.9 , cw 8.8 to 10.0 (MZUSP 11107), locality unknown.

Pisidia brasiliensis Haig in Rodrigues da Costa, 1968: 1 ovigerous female, cl 4.4, cw 4.7 ( $\mathrm{MHNCl}$ 3840), Brazil, Santa Catarina, Penha, Armação de Itapocoroy, P.P.B. Macedo coll., 20.vi.2011, associated with Nodipecten nodosus; 1 male, cl 3.6, cw 3.7, 2 ovigerous females, cl 4.1, cW 4.3 and cl 4.8, cw 5.0 ( $\mathrm{MHNCl}$ 3684), same locality, P.P.B. Macedo coll., associated with Nodipecten nodosus; 2 ovigerous females, cl 3.7, cw 3.9 and cl 4.0, cw 4.2 (MHNCl 3130), same locality, P.P.B. Macedo coll., 14.vii.2010, associated with Nodipecten nodosus. The above specimens were reported by Macedo et al. (2012) as P. platycheles.

Type locality: Brazil, São Paulo, São Sebastião, Praia de São Francisco.

Redescription of the lectotype: Carapace subcircular, longer than broad in males and females, slightly rugose dorsally, pubescent. Front-orbital region depressed, smooth. Frontal width approximately $1 / 3$ maximum carapace width. Frontal margin serrate, fringed with short setae; trilobate in dorsal and frontal views; median lobe rounded, overreaching lateral lobes; lateral lobes rounded. Outer orbital angle well defined, rounded, with spinulate margin. Carapace anterolateral margin spinulate. Carapace lateral margin well-defined by row of conspicuous spines. Epibranchial region slightly swollen. Epibranchial angle well-defined by distinct notch; cervical groove well-defined. Carapace posterolateral surface plicate; posterior margin concave. Branchiostegite entire (without membranous areas), with longitudinal, subparallel, pilose wrinkles; superoanterior region spinulate. Branchiostegal margin fringed with long, plumose setae.

Ocular peduncle short, smooth. Orbit with smooth margin, fringed with short setae. Cornea large, dilated.

Antennular basal segment large, 2 anteromesial spines, 1 anterolateral spine. Segments 2 and 3 unarmed, subcylindrical; segment 3 as long as segment 2, slightly broadened distally.

Antennal segments covered with short setae. Coxa subtriangular, with granulate margins. Basis-ischium approximately $2 / 3$ length of merus, spinulate mesially; distal tubercle on mesial surface. Merus granulate mesially. Carpus approximately half of total length of merus. Flagellum long; short articles with inconspicuous setae.

Mxp 3 dorsal surface smooth, covered with short setae. Exopod slender, lanceolate, reaching half total length of merus, fringed with long, plumose setae; flagellum well developed. Ischium lateral lobe long, separated by V-shaped incision. Merus as long as ischium; mesial lobe broad, rounded, with small spine mesially.

Thoracic sternite 3 median lobe broad anteriorly, rounded, fringed with short, setae; lateral lobes narrow, subtriangular, slightly shorter than median lobe. Sternites 4-7 broad, sutures between sternites incomplete, distinct only laterally. Sternite 8 anterior margin convex, posterior margin concave.

P1 slightly unequal, robust, flattened, covered with dense, short setae dorsally; propodus and dactylus with sparse granules, more evident next to pollex; smooth ventrally, devoid of setae. Merus approximately $1 / 4$ length of carpus; mesial lobe well-developed, rounded, spinulate; distal spine ventrally. Carpus approximately half length of propodus, with subtriangular, spinulate lobe on proximal third mesially; distal spine laterally, lateral margin with row of spines. Propodus broad, lateral margin with row of spines; fringed with long, dense, plumose setae laterally. Fixed finger approximately $1 / 3$ total length of propodus; not overreaching dactylus. Dactylus longer than fixed finger. Fingers tip curved; cutting edges of fingers with conspicuous granules, with traces of short setae.

Walking legs decreasing in size from $\mathrm{P} 2$ to $\mathrm{P} 4$, slender, covered with long, dense, plumose setae. P2-P4 carpi approximately $2 / 3$ length of meri. P2-P4 carpi approximately $2 / 3$ length of propodi. P2-P4 propodi with 3 movable, corneous spines ventrally, 1 on distal third, 2 on distal 

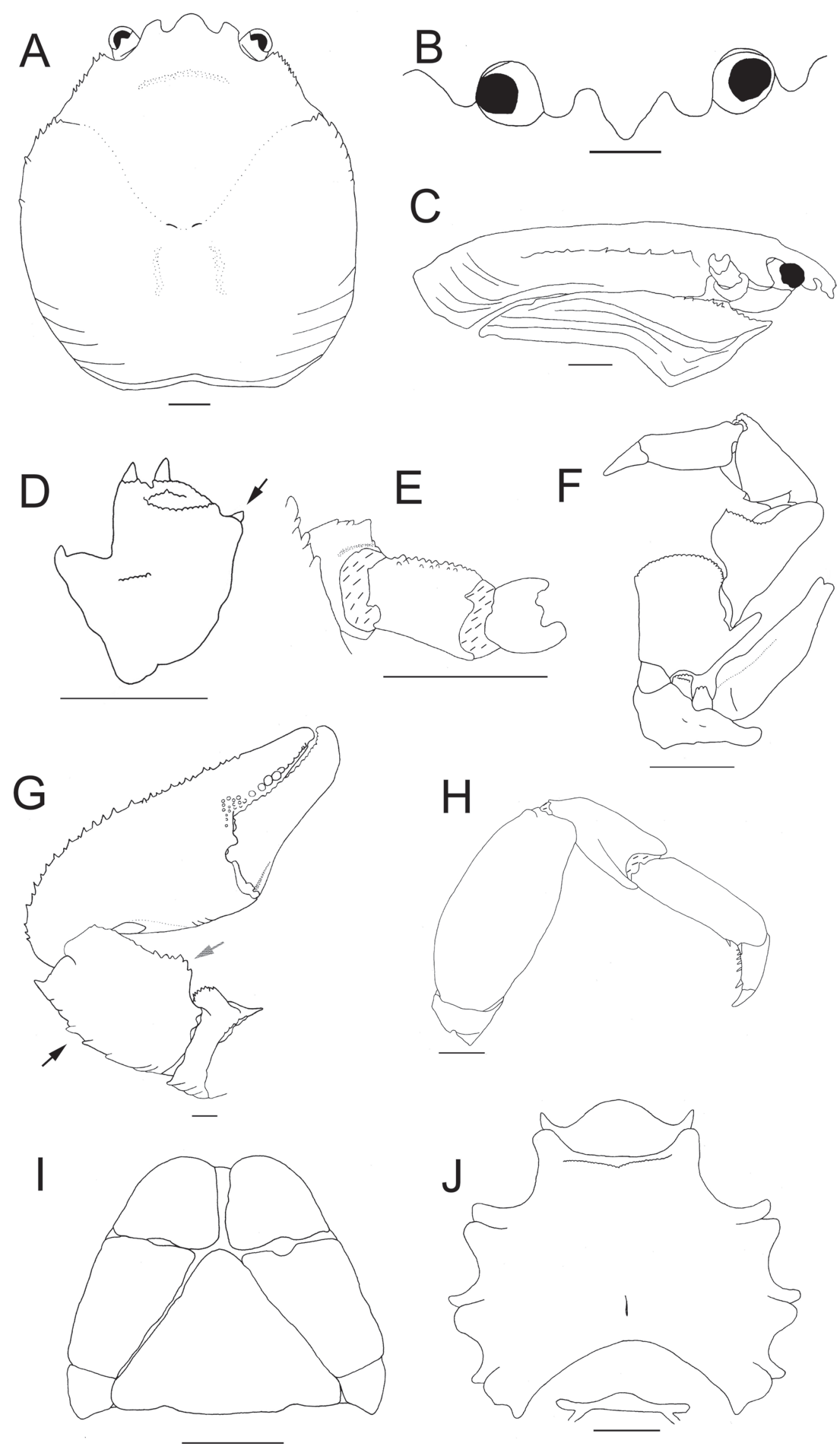

Figure 1. (A-J) Porcellana paivacarvalhoi Rodrigues da Costa, 1968, male lectotype, cl $10.3 \mathrm{~mm}$, cw $9.6 \mathrm{~mm}$ (MZUSP 40050). (A) Carapace, dorsal view. (B) Frontalorbital region of carapace, frontal view. (C) Carapace, lateral view, emphasizing branchiostegite. (D) Left basal segment of antennule, ventral view. The arrow points to the anterolateral spine. (E) Left antenna, lateral view (flagellum omitted). (F) Left Mxp 3, ventral view (flagellum of exopod omitted). (G) Left major P1, dorsal view. The black and grey arrows point to the carpal lateral spines and mesial lobe, respectively. (H) Right P4, lateral view. (I) Telson, dorsal view. (J) Thoracic sternum, ventral view. Setae omitted. Scale bars: $1 \mathrm{~mm}$. 


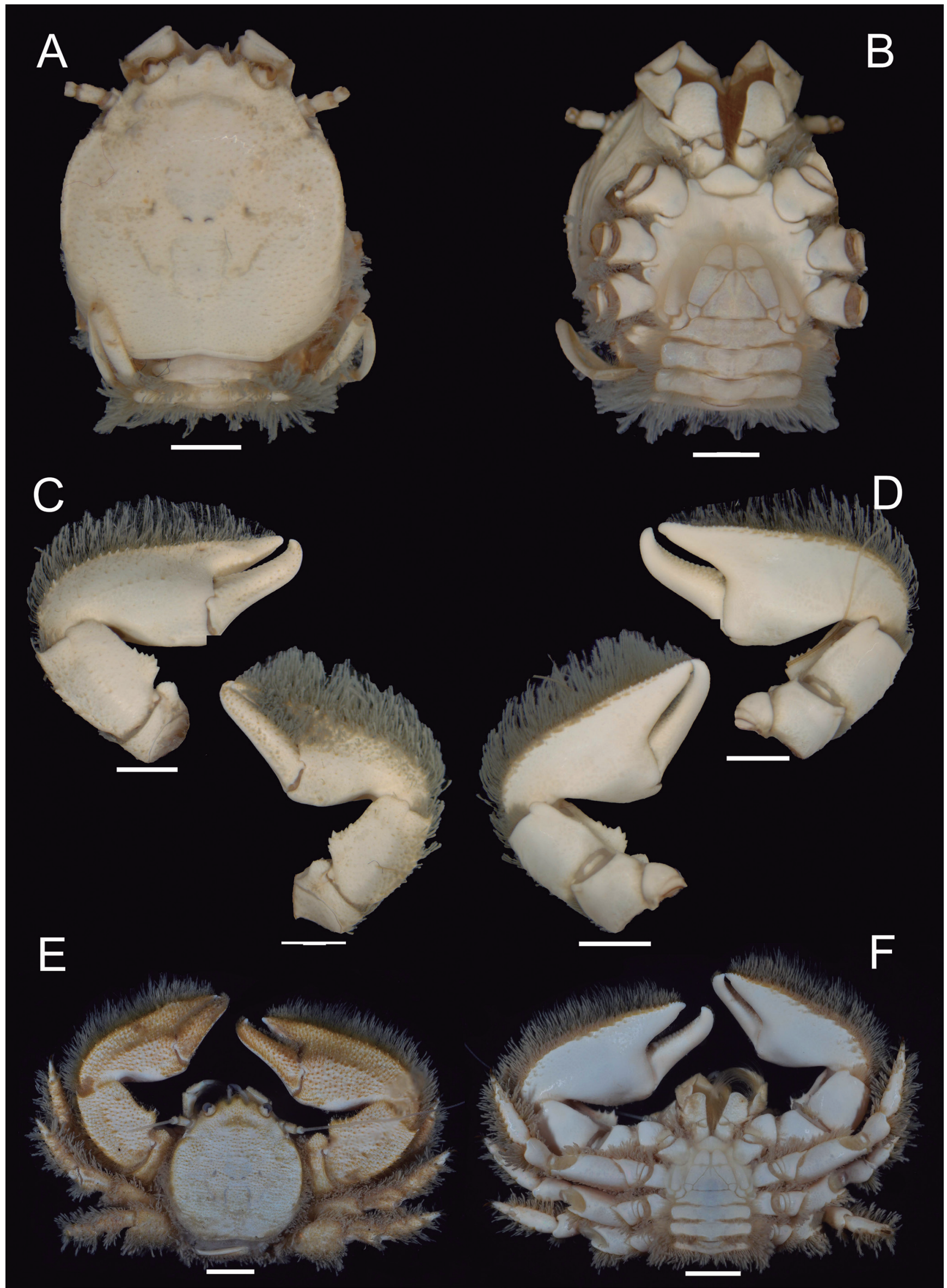

Figure 2. (A-D) Porcellana paivacarvalhoi Rodrigues da Costa, 1968, male lectotype, cl 10.3 mm, cw 9.6 mm (MZUSP 40050). (A) Cephalothorax, dorsal view. (B) Cephalothorax, ventral view. (C) Major and minor P1, dorsal views. (D) Minor and major P1, ventral views. (E, F) Porcellana platycheles (Pennant, 1777), male, cl 8.2 mm, cw $7.8 \mathrm{~mm}$ (MZUSP 36759), habitus, dorsal and ventral views, respectively. Color in ethanol. Scale bars: $3 \mathrm{~mm}$. 

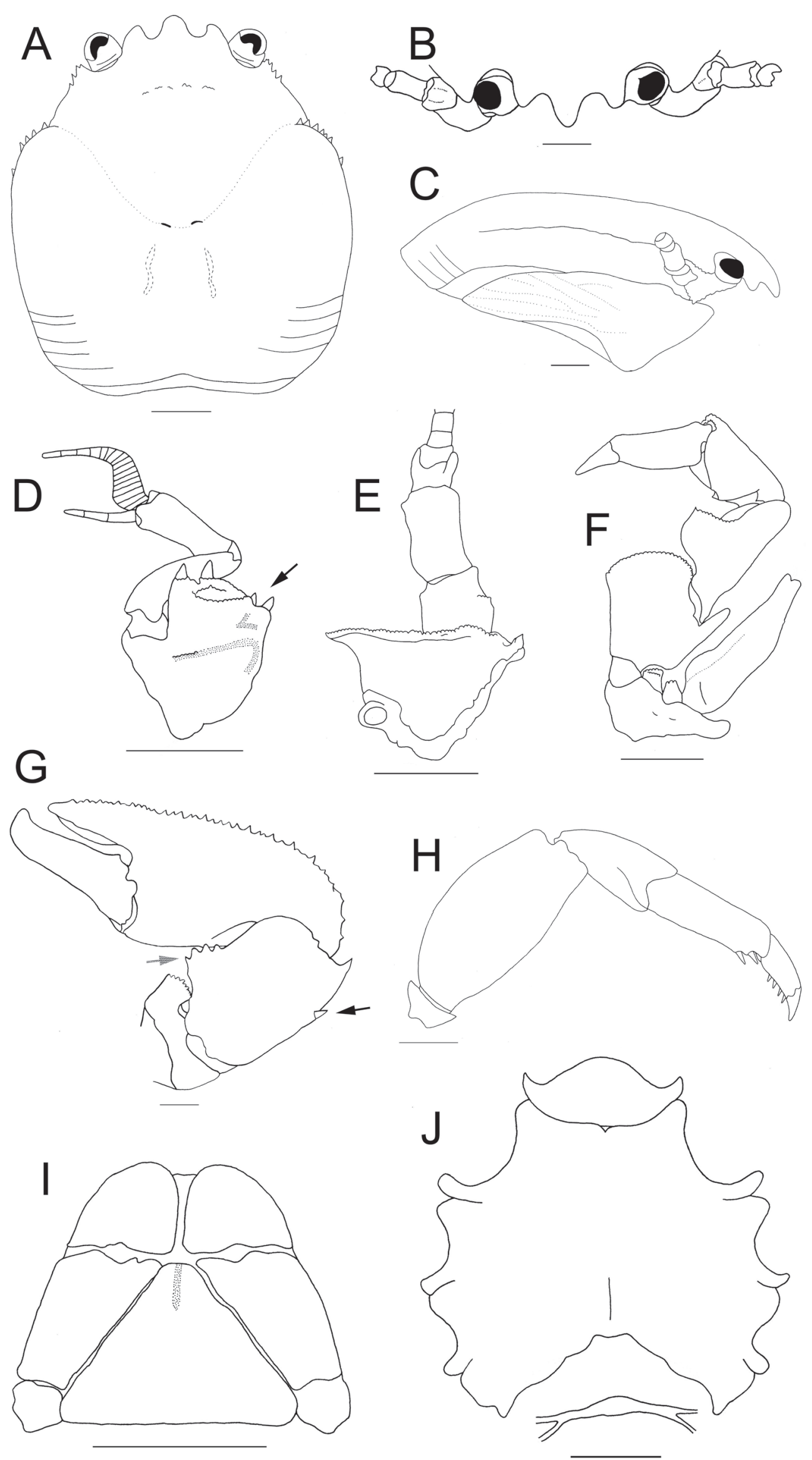

Figure 3. Porcellana platycheles (Pennant, 1777), male, cl 8.2 mm, cw 7.8 mm (MZUSP 36759). (A) Carapace, dorsal view. (B) Frontal-orbital region of carapace, frontal view. (C) Carapace, lateral view, emphasizing branchiostegite. (D) Left antennule, ventral view. The arrow points to the anterolateral spines. (E) Left antenna, ventral view. (F) Left Mxp 3, ventral view (flagellum of exopod omitted). (G) Right major P1, dorsal view. The black and grey arrows point to the carpal lateral spine and mesial lobe, respectively. (H) Right P4, lateral view. (I) Telson, dorsal view. (J) Thoracic sternum, ventral view. Setae omitted. Scale bars: $1 \mathrm{~mm}$. 
corner near articulation with dactylus; P2-P4 dactyli approximately half length of propodi; longitudinal row of 5 spines ventrally.

Abdomen subrectangular in males and females, somites smooth dorsally, lateral margins with long, plumose setae. Male gonopods well-developed on somite 2; female pleopods well-developed on somites 3-5. Uropods slender, reaching distal margin of telson. Telson smooth dorsally, broader than long, subdivided into 7 plates.

Remarks: Porcellana paivacarvalhoi was established based on 4 males and 3 females from southeastern Brazil (São Francisco beach, São Sebastião, São Paulo), one male and one female of which remain in the collections of the MZUSP and one additional female was retrieved from MOUFPE. The syntypes were originally in Rodrigues' da Costa collection and, after his death, the remains of his original collections were donated to MZUSP. The female housed at the MOUFPE was a donation from MZUSP. The male syntype is better preserved than either of the females and therefore is herein chosen as the lectotype (MZUSP 40050, Figs. 1A-J; 2A-D). The females (MZUSP 10621; MOUFPE 7734) are the paralectotypes. The designation of the lectotype and its redescription and illustration are made in an effort to clarify the identity of the species and promote nomenclatural stability.

Rodrigues da Costa (1968) stated that P. paivacarvalhoi was similar to the eastern Atlantic P. platycheles and, more particularly, to the west African P. platycheles africana Chace, 1956. Veloso \& Melo (1993) placed $P$. paivacarvalhoi in synonymy with $P$. platycheles based on the examination of one "male paratype" [sic] (MZUSP 8951). That specimen no longer exists in the MZUSP collections, however there is no evidence that it was indeed a syntype, and it is unclear from their publication whether Veloso \& Melo ever compared the purported syntype of $P$. paivacarvalhoi with specimens of $P$. platycheles. Furthermore, they never addressed the morphological similarities between $P$. paivacarvalhoi and $P$. africana, whose specific status has recently been confirmed by Griffiths et al. (2018) (see also d'Udekem d'Acoz, 1999). Despite this, the synonymy between $P$. paivacarvalhoi and $P$. platycheles has been implicitly accepted without further analysis (Melo, 1999; Rodríguez et al., 2005; Osawa \& McLaughlin, 2010; Griffiths et al., 2018).

Porcellana paivacarvalhoi resembles $P$. africana in having the lateral margin of the P1 carpus armed with one conspicuous terminal spine, but can be distinguished from it in that the lateral margin of the $\mathrm{P} 1$ carpus is armed with 1, 2 or more spines of different sizes (Figs. 1G; 2C, D). Conversely, the lateral margin of the P1 carpus has no spines other than the distal one in P. africana (Chace, 1956; Griffiths et al., 2018). Porcellana africana further differs in being overall less spinose and more tuberculate and rugose beneath the pubescence covering the carapace, whereas the carapace is nearly smooth dorsally in P. paivacarvalhoi (Figs. 1A; 2A). Porcellana paivacarvalhoi is not, therefore, a synonym of $P$. africana.
In P. paivacarvalhoi, as in P. platycheles, the carapace is nearly smooth dorsally, whilst its anterolateral and lateral margins have conspicuous spinules (Figs. 1A, C; 2A; 3A); the carapace and $\mathrm{P} 1$ dorsal surfaces are provided with either short or long setae; the antennular basal segment with 1 or 2 anterolateral spines (Figs. 1D; 3D); the lateral margin of the $\mathrm{P} 1$ carpus is armed with 1, 2 or more spines of different sizes (Figs. 1G; 3G); the P1 carpus mesial lobe is either well developed (Figs. 1G; 3G) or inconspicuous; and the P2-P4 dactyli have a longitudinal row of 5 or 4 spines ventrally (Figs. $1 \mathrm{H} ; 3 \mathrm{H}$, respectively). In addition to the P1 lateral spines, P. paivacarvalhoi further resembles $P$. platycheles in having conspicuous spinules on both the anterolateral and lateral margins of the carapace, and a nearly smooth carapace and P1. In these and other respects $P$. paivacarvalhoi lacks sufficient morphological differences to be recognized as a separate species from $P$. platycheles and, therefore, is confirmed herein to be its junior synonym.

The native range of Porcellana platycheles is in the eastern Atlantic (from Ireland southward to the Canary Islands) and in the Mediterranean Sea, from the intertidal zone down to $5 \mathrm{~m}$ (d'Udekem d'Acoz 1999). Its presence in São Sebastião in southeastern Brazil in the late 1960s most probably represents an historical case of human-mediated introduction by shipping activities. Indeed, São Sebastião, which started operation in 1963, is a busy city port catering to ocean-going vessels. The repeated presence of eastern Atlantic/Mediterranean species in southeastern Brazil (Tavares, 2011; Tavares \& Mendonça, 2004; Tavares \& Rössener, 2019; this report), indicates human-mediated connectivity between eastern Atlantic source areas and Brazilian points of entry and is a reflection of the level of inoculation pressure in the 1960s.

Porcellana platycheles did not manage to establish itself in São Sebastião, nor has it been recorded subsequently from elsewhere in Brazil. Macedo et al. (2012) reported on 1 male and 5 females ( $\mathrm{MHNCl} 3840,3684$, 3130) purportedly belonging to $P$. platycheles associated with mussel farming in Santa Catarina, south Brazil. However, upon examination all these specimens proved to be Pisidia brasiliensis Haig in Rodrigues da Costa, 1968.

\section{ACKNOWLEDGEMENTS}

We gratefully thank Jesser Fidelis de Souza Filho (UFPE) and Odete Lopez Lopes (MHNCI) for enabling us to study the material under their responsibility. We also thank Joana d'Arc de J. Pinto and Maria José de S. Coelho (both from MZUSP) for their kind assistance throughout the execution of this work. Comments from an anonymous reviewer helped to improve the final version. MT thanks CNPq (PROTAX, 440426/2015-4) for financial support through a post-doctoral fellowship to LAAF and CNPq (Produtividade, 303122/2016-1) for funding studies on the taxonomy of decapod crustaceans. 


\section{REFERENCES}

Chace, F.A. 1956. Expédition océanographique Belge dans les eaux côtiéres africaines de I'Atlantique Sud (1948-1949). Résultats Scientifiques, 3(5): 17-43.

d'Udekem d'Acoz, C. 1999. Inventaire et distribution des crustaces decapodes de l'Atlantique nord-oriental, de la Mediterranee et des eaux continentales adjacentes au nord de 250N. Paris, Patrimoines naturels, Museum National d'Histoire Naturelle. 383p.

Griffiths, C.L.; Roberts, S.; Branch, G.M.; Eckel, K.; Schubart, C.D. \& Lemaitre, R. 2018. The porcelain crab Porcellana africana Chace, 1956 (Decapoda: Porcellanidae) introduced into Saldanha Bay, South Africa. Biolnvasions Records, 7(2): 133-142.

Haworth, A.H. 1825. A new binary arrangement of the macrurous Crustacea. Philosophical Magazine, 65: 107-108.

Lamarck, J.B. 1801. Système des animaux sans vertèbres, ou Tableau general des classes, des ordres et des genres de ces animaux. Paris, Chez le Auteur. 432p.

Macedo, P.P.B.; Masunari, S. \& Corbetta, R. 2012. Crustáceos decápodos associados às cordas de cultivo do mexilhão Perna perna (Linnaeus, 1758) (Mollusca, Bivalvia, Mytilidae) na Enseada da Armação de Itapocoroy, Penha, SC. Biota Neotropica, 12(2): 185-195.

Melo, G.A.S. 1999. Manual de identificação dos Crustacea Decapoda do litoral brasileiro: Anomura, Thalassinidea, Palinuridea, Astacidea. São Paulo, Editora Plêiade Fapesp. 556p.

Osawa, M. \& McLaughlin, P.A. 2010. Annotated checklist of anomuran decapod crustaceans of the world (exclusive of the Kiwaoidea and
Families Chirostylidae and Galatheidae of the Galatheoidea) Part II Porcellanidae. The Raffles Bulletin of Zoology, 23: 109-129.

Pennant, M.J. 1777. Crustacea, Mollusca, Testacea. London, British Zoology. $154 p$.

Rodrigues da Costa, H. 1968. Novas espécies de Porcellanidae brasileiros (Crustacea: Anomura). Anais da Academia Brasileira de Ciências, 40(3) 405-406.

Rodríguez, I.T.; Hernández, G. \& Felder, D.L. 2005. Review of the western Atlantic Porcellanidae (Crustacea: Decapoda: Anomura) with new records, systematic observations, and comments on biogeography. Caribbean Journal of Science, 41(3): 544-58.

Tavares, M. 2011. Alien decapod crustaceans in the Southwestern Atlantic Ocean. In: Galil, B.S.; Clark, P.F. \& Carlton, J.T. (Eds.). In the wrong place - alien marine Crustaceans: distribution, biology and impactsInvading Nature. Dordrecht, Springer. p. 251-268. (Springer Series in Invasion Ecology, v. 6)

Tavares, M. \& Mendonça, J.B. 2004. Introdução de crustáceos decápodes exóticos no Brasil: uma roleta ecológica. In: Água de lastro e bioinvasão. Rio de Janeiro, Interciência. p. 59-76.

Tavares, M. \& Rössener, E. 2019. Occurrence of the eastern Atlantic, Mediterranean, and Black Sea swimming crab Liocarcinus depurator (Linnaeus, 1758) (Brachyura: Carcinidae) in the Western Atlantic. Journal of Crustacean Biology, 39(2): 193-195.

Veloso, V.G. \& Melo, G.A.S. 1993. Taxonomia e distribuição da família Porcellanidae (Crustacea: Decapoda: Anomura) no litoral brasileiro. Iheringia, Série Zoologia, 75: 171-186. 